International Research Journal of Management, IT \& Social Sciences
Available online at https://sloap.org/journals/index.php/irjmis/
Vol. 7 No. 5, September 2020, pages: 38-45
ISSN: 2395-7492
https://doi.org/10.21744/irjmis.v7n5.966

\title{
The Feasibility Study of Coffee House Business Opportunity in COVID-19 Pandemic: A Case Study at Kulo Coffee Shop Pemogan
}

\author{
Ni Wayan Ari Sudiartini ${ }^{\text {a }}$ \\ Anak Agung Elik Astari ${ }^{b}$ \\ Ni Luh Kardini ${ }^{c}$ \\ Yenni Rahman Dhani ${ }^{\mathrm{d}}$
}

Article history:

Submitted: 27 May 2020

Revised: 18 June 2020

Accepted: 01 August 2020

\section{Keywords:}

business feasibility study;

covid 19;

kulo coffee shop pemogan;

pandemic;

swot;

\begin{abstract}
In running a business, there are certainly a lot of things to be aware of. Anything that can affect the company needs to be taken into account. Through the business feasibility study, business owner can be aware of the information regarding current business position. The information is used as a reference for the owner to run the business ahead. Kulo coffee shop Pemogan is currently facing a situation that requires the owner to be more creative and innovative amid similar business competition that is very strict especially in COVID-19 pandemic. This business feasibility study applied quantitative and qualitative data analysis techniques. Data were obtained through interviews, observations, and documentations conducted at the Kulo coffee shop Pemogan. The data obtained from the research object were then immediately collected and processed. The stages conducted in analyzing the feasibility are through aspects such as market and marketing aspects, legal aspects, technical and technological aspects, environmental aspects, and financial aspects. In finding out the business opportunity of Kulo coffee shop Pemogan, SWOT analysis was done. It consisted of strengths, weaknesses, opportunities, and threats of this business.
\end{abstract}

International research journal of management, IT and social sciences (C) 2020. This is an open access article under the CC BY-NC-ND license (https://creativecommons.org/licenses/by-nc-nd/4.0/).

Corresponding author:

Sudiartini N.W.A.

Lecturer Mahendradatta University, Bali, Indonesia

Email address: wayan.ari1987@gmail.com

\footnotetext{
${ }^{a}$ Faculty of Economic, Mahendradatta University, Bali, Indonesia

${ }^{b}$ Faculty of Economic, Mahendradatta University, Bali, Indonesia

Faculty of Economic, Mahendradatta University, Bali, Indonesia

${ }^{d}$ Faculty of Economic, Mahendradatta University, Bali, Indonesia
} 


\section{Introduction}

Coffee has been one of the best-known drinks and one of the favorites since the beginning even until now. Consuming coffee has not only become a habit for the olds, nowadays even the youngs are also an enthusiast in consuming coffee (Barusman \& Khunsu, 2013; Rahayu, 2015; Purnamasari \& Hendrawan, 2013). Indonesia is a country capable of producing more than 400 thousand tons of coffee per year and has been supplying about $9 \%$ of the world's coffee production (Keizer et al., 1984; Henderson et al., 2009). The opportunity to increase the productivity of Indonesian coffee plants is widely open because Indonesia has a tropical climate which is a good climate for coffee plants. In 2012, the sum of the coffee plantation area in Indonesia reached 1.233.982 hectares. The lifestyle growth and change of Indonesian people resulted in the performance of the coffee processing industry in the country experience a significant increase so that, currently, the coffee industry in Indonesia is accelerated in its development (Cope, 1995; Roth \& Aretz, 1991; Kramers \& Smith, 1983; Unno et al., 2008).

As the time goes by, coffee products nowadays are not only in form of ground coffee (roasted and ground) but there is a wide variety of diversified processed coffee products such as instant coffee, three in one coffee, coffee drinks with various flavors such as vanilla, cocoa, and others. The growth of the coffee processing industry is characterized by the presence of roastery, cafes, and coffee shops. One of the trends that are currently growing is the coffee shop. It is a place that provides coffee with its derivatives as the main beverage and various types of drinks (side drinks) such as chocolate, matcha, and others. Coffee shops are also placed for people who just want to relax or do other activities such as discussions, reading printed media, online or books, completing some academic or non-academic assignments, or to simply enjoy the entertainment offered (Nurazizi, 2013). Chairman Specialty Coffee Association of Indonesia (SCAI) revealed, currently the coffee shop's contribution to the domestic production coffee uptake is $25 \%-30 \%$. The figure continues to rise to level $35 \%-40 \%$ by the end of 2019 and is expected to continue to evolve year after year.

The development of the coffee industry in Indonesia greatly impacts the growth of coffee shops in Bali. Bali is one of the provinces that produce a good and promising coffee commodity (Wulandari, 2012; Putra \& Azis, 2018; Kogan, 1998). People's habit to consume coffee and improve public knowledge about coffee encourages people to use this opportunity to open a business which is believed would make a big profit. Bali is an island that is identical to tourist destinations for both domestic and international tourists, therefore coffee shops and cafes are often seen in every corner of the island. The culture of coffee drinking has become a habit of local people and tourists which turned Bali as one of the regions with the highest consumption of coffee.

Table 1

10 Highest Coffee Consumption Region

\begin{tabular}{llll}
\hline No. & Cities/Regencies Region & Coffee Consumption & Rank \\
\hline 1 & Sumatra & 2.473 oz/capita/month & 8,10 \\
2 & Java & No city/regency in Java is in the top 10 & \\
3 & Bali \& Nusa Tenggara & 4.271 oz/capita/month & $2,5,7$ \\
4 & Sulawesi & 3.261 oz/capita/month & $4,6,9$ \\
5 & Maluku \& Papua & 10.149 oz/capita/month & 1,3 \\
6 & Kalimantan & No city/regency in Kalimantan is in top & \\
& & 10 & \\
\hline
\end{tabular}

Source: Coffee consumption by region in 2018 , lokadata by beritaagar.id

The development of technology and public knowledge regarding the management of coffee shops increased the competition of similar businesses. Denpasar in particular now has a lot of coffee shops.

Sudiartini, N. W. A., Astari, A. A. E., Kardini, N. L., \& Dhani, Y. R. (2020). The feasibility study of coffee house business opportunity in COVID-19 pandemic: a case study at kulo coffee shop pemogan. International Research Journal of Management, IT and Social Sciences, 7(5), 38-45. https://doi.org/10.21744/irjmis.v7n5.966 
Table 2

Coffe Shop in Denpasar

\begin{tabular}{lll}
\hline No. & Region & Outlet Number \\
\hline 1 & North Denpasar & 9 \\
2 & East Denpasar & 11 \\
3 & West Denpasar & 13 \\
4 & South Denpasar & 27 \\
\hline
\end{tabular}

Source: Data Processed

Lately, Indonesia including Bali is being surprised by the spread of Coronaviruses or the so-called COVID-19. The outbreak is rapidly spreading to various countries in the world which forced the World Health Organization (WHO) to proclaim the outbreak of the virus spread of COVID-19 as the world pandemic. Many people have been infected. The deaths reported for COVID-19 are about 3.4\%. One of the government's efforts to break the chain of the spread is by doing physical distancing. Physical distancing is the appeal to keep the distance between people, avoiding activities in all forms of crowds, associations, and avoiding meetings involving many people.

One of the factors that cause sales decline is that, besides local customers, Kulo coffee shop Pemogan is often visited by foreigners. Kulo coffee shop Pemogan is located on Jalan Raya Pemogan, a very crowded area as it is close to bypass Ngurah Rai which connects Badung, Denpasar, and Gianyar. Also, the distance of tourist attractions in Denpasar and Kuta is very close and easy to reach, resulting in most customers who come are from tourism sectors. But since Bali was exposed to the COVID-19 pandemic, the tourism sector has not been doing good (Romdhon et al., 2018; Jani, 2018; Putri et al., 2020). Judging from the stay of the tourists in Bali monthly, Bali tourism has lost Rp. 9,7 trillion per month during the pandemic (Deputy governor of Bali Tjok Oka Artha Ardhana Sukawati, Merdeka.com 2020). Thus, it certainly has a significant impact on the customer visit of the Kulo coffee shop Pemogan. The data on the number of foreign tourists visit per month that came to Indonesia is based on the air entrance at Ngurah Rai Airport before and after the COVID-19 pandemic (Rangkuti, 1998; Winantara et al., 2014; Khamaludin et al., 2019).

\section{Materials and Methods}

Research design is the process of collecting and analyzing the data. The purpose of the research design is to provide plans or stages to answer the research problem. The design of this research includes quantitative and qualitative methods. Business feasibility is analyzed based on related aspects and SWOT analysis. This research was conducted in three months from March to May 2020.

According to Sugiyono (1997) stated population is an area of generalization consisting of objects or subjects that have specific quantities and characteristics set by researchers to learn from and then the conclusion is withdrawn. "The population in this study is the Kulo coffee shop Pemogan.

Data analyzing techniques are the way that researchers use to process the data that has been obtained from the objects of the study. The data processing in this study was done qualitatively and quantitatively. Qualitative data processing was used to analyze non-financial aspects that include legal aspects, market and marketing aspects, technical and technological aspects, and environmental aspects. Quantitative data processing was used to analyze financial aspects by calculating the net present value (NPV), internal rate of return (IRR), and payback period (PP). 


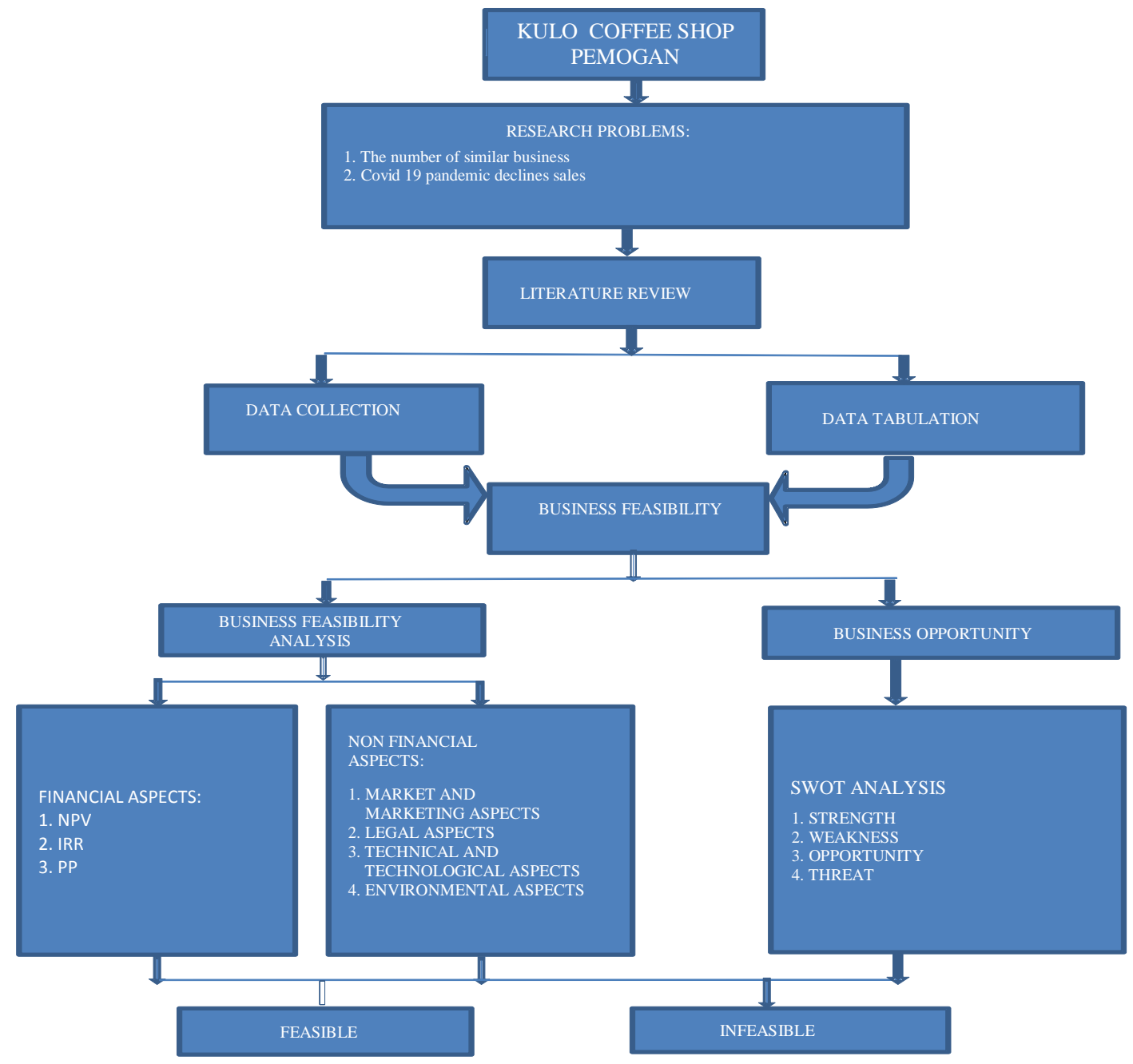

Figure 1. Framework

\section{Results and Discussions}

Coffee shop Kulo is one of the businesses that focus on processed coffee which is a franchise formed by Kulo Group. Kulo Group comes with a wide range of F\&B brands such as Pochajjang for Korean BBQ, Kitamura Shabu-Shabu, and Kulo Coffee. Kulo Coffee was established in 2017. Kulo Coffe was founded by Michelle Sulistyo with five of her colleagues. This business idea is inspired by her favorite drink, Avocatto a blend of avocado juice, espresso, and ice cream that then became the start of the business.

\subsection{Business Feasibility Analysis}

a) Legal Aspects

Legal aspects are the aspects that examine the legal provisions or licensing of a business based on the business field. This aspect must be designed from the beginning before the company is developed. Some of the things that need to be considered are to make a Disturbance Permit (HO), Business Permit (SITU), and also a Business License (SIUP), as well as register the business at the company registration (TDP). Also, F\&B business needs the halal certification and cleanliness certification from the Bali Provincial health office. This business entity is an individual company by completing the NPWP of the owner.

Sudiartini, N. W. A., Astari, A. A. E., Kardini, N. L., \& Dhani, Y. R. (2020). The feasibility study of coffee house business opportunity in COVID-19 pandemic: a case study at kulo coffee shop pemogan. International Research Journal of Management, IT and Social Sciences, 7(5), 38-45. https://doi.org/10.21744/irjmis.v7n5.966 
b) Market and Marketing Aspects

Market and marketing aspects are very important to analyze because with them, the business owner can determine the market segment that will be intended. Geographically, Kulo coffee shop is located in Denpasar City in which most of the people there are categorized in middle and upper economy classes. Market selection strategy is done based on the observation, that the target of Kulo coffee shop Pemogan is at all levels but is more focused on the upper-middle class. The products offered, packaging standard and the presentation of the product are all in line with the target market that is intended. Kulo coffee shop Pemogan should find the most suitable market because good sales depend on the markets and consumers.

c) Technical and Technological Aspects

Technical and technological aspects related to the location of the business so that it gets the floor plan and overview that is applied to the location of the coffee shop. Also, this aspect discusses the source of raw materials, where raw materials can be easily obtained, and the scheduling of effective stock equipment that reduces the presence of problems in the production process. Kulo coffee shop Pemogan fulfills some criteria points that must be owned by a coffee shop in determining the location of the business, selected raw materials, the scheduling of raw materials completeness, tools and their maintenance, and Kulo coffee shop Pemogan is very attentive to the customer's waiting time which adds the value of Kulo coffee shop Pemogan service quality.

d) Environmental Aspects

Environmental aspects are the things that a company should consider because some of the contributions to the community and surrounding environment include the absorption of manpower, provision of employment, and contributions to the development and income of the region as well as the impacts from the activities of the coffee shop to the surrounding environment. Negligence in this aspect can result in the rejection of the community around the place towards business production and sustainability. Kulo coffee shop Pemogan does not pollute either on soil fertility, water, air, and noise. The waste produced at the production of Kulo coffee shop is coffee waste which does not pollute the soil. Also, they produced plastic waste. However, it is well managed by throwing them to the trash bin. While some plastic and glass bottles are recycled by giving them to the second-hand piner.

e) Financial Aspects

The financial aspect is an aspect that determines the funding source by calculating the rate of reimbursement of investment and feasibility based on the profit generated. In analyzing the financial aspects of Kulo coffee shop Pemogan, the calculation of income since the opening of the coffee shop is used. The table below shows that the total PV net cash is Rp 512.546.296. Then the calculation of PV net cash investment from the first to the third year is.

Table 3

NPV Calculation

\begin{tabular}{lllll}
\hline No. & Year & Net Profit (Rp) & Discount 20\% & Net PV \\
\hline 1 & I & IDR. 201.000.000 & 0,833 & IDR. 167.500.000 \\
2 & II & IDR. 295.700.000 & 0,694 & IDR. 205.347.222 \\
3 & III & IDR. 241.400.000 & 0,579 & IDR. 139.699.074 \\
\multicolumn{2}{l}{ Total } & & & IDR. 512.546.296 \\
\hline
\end{tabular}

IRR is a formula to indicate how many percent (\%) the return on investment annually. The calculations are as follows:

Table 4

IRR Calculation (Internal Rate of Return)

\begin{tabular}{lllllll}
\hline \multirow{2}{*}{ No. } & \multirow{2}{*}{ Year } & \multirow{2}{*}{ Net Cash } & \multicolumn{2}{l}{ 20\% Interest } & \multicolumn{2}{l}{ 43\% Interest } \\
\cline { 4 - 6 } & & DF & Net PV Cash & DF & Net PV Cash \\
\hline 1 & I & IDR. 167.500.000 & 0,8333 & IDR. 201.080.432 & 0,7 & IDR. 140.615.687 \\
2 & II & IDR. 205.347.222 & 0,694 & IDR. 295.889.369 & 0,49 & IDR. 144.696.254
\end{tabular}




\begin{tabular}{lcllll}
\hline $3 \quad$ III & IDR. 139.699.074 & 0,579 & IDR. 241.276.466 & 0,34 & IDR. 117.874.086 \\
& Net PV Cash & Total & IDR. 738.246.466 & Total & IDR. 403.186.027 \\
Investment & & & IDR. 250.000.000 & & IDR. 250.000.000 \\
NPV & & & IDR. 488.246.466 & & IDR. 153.1866.027 \\
\hline
\end{tabular}

PP is a formula to find out how long the return time is. The calculations are in table 5. So the return of capital on investment for 1 year 5 months will be completed in the second year.

Table 5

Payback Periode Calculation

\begin{tabular}{llll}
\hline No. & Year & Net Cash (IDR) & Cumulative Net Cash (IDR) \\
\hline 1 & I & IDR. 167.500.000 & IDR. 167.500.000 \\
2 & II & IDR. 205.347.222 & IDR. 372.847.222 \\
3 & III & IDR. 139.699.074 & IDR. 512.546.296 \\
\hline
\end{tabular}

\subsection{SWOT Analysis}

SWOT analysis is an analysis of the internal and external conditions of an organization that will later be used as the basis for designing the company's strategy and work program. The internal analysis includes assessments of strength and weakness and external analysis including opportunity and threat factors. As for the SWOT analysis of the Kulo coffee shop Pemogan are as follow:

a) Strength

- Coffee is a drink that is always on demand.

- Kulo coffee shop has a brand name that is well known to many people both local and national.

- Have a variety of variants with processed coffee so that it can be consumed by kids and adults.

- Located in a strategic business location.

- Easy to obtain raw production materials.

- Has a cozy place to stay.

b) Weakness

- Coffee shop Kulo Pemogan is a franchise so that product innovation is limited.

- The raw materials used are not sold freely in the market.

- The capital is big enough to start a business.

- The product price is quite expensive.

- Requires employees who are good at making coffee.

c) Opportunity

- The community demand for coffee is high.

- High level of community prestige to choose a place to hang out.

- Internet needs for students and students.

- The limited number of the coffee shop that has a variant of foreign flavors.

d) Threat

- Many similar businesses with competitive advantages.

- Increase in production materials.

\section{Conclusion}

Based on preceding analysis and discussion, it can be concluded that:

1) Kulo coffee shop Pemogan is worth running because judging from the market and marketing aspects, legal aspects, technical and technological aspects, and the environmental aspects, it has fulfilled the criteria. Meanwhile, from the financial aspects, Kulo coffee shop Pemogan is a decent business despite the decline in

Sudiartini, N. W. A., Astari, A. A. E., Kardini, N. L., \& Dhani, Y. R. (2020). The feasibility study of coffee house business opportunity in COVID-19 pandemic: a case study at kulo coffee shop pemogan. International Research Journal of Management, IT and Social Sciences, 7(5), 38-45. https://doi.org/10.21744/irjmis.v7n5.966 
the last year's revenue that was caused by the COVID-19 pandemic. However, the NPV (Net Present Value) of Kulo coffee shop Pemogan is 262,546,296 which is higher than 0. The IRR value (Internal Rate of Return) is $54 \%$ which is higher than the bank's loan interest rate and the period of payback of 4.82 so the return on investment is for 1 year 5 months will be completed in the second year. Thus, it can be concluded that this business is worthy to run.

2) SWOT analysis resulted in internal matrix 2.67 and external matrix 2.01. This indicates that the business position of Kulo coffee shop Pemogan is in the position of $\mathrm{V}$ with a stability strategy. Thus, the position of this business does have weaknesses and threats resulting in Kulo coffee shop Pemogan must utilize the SO strategy (Strength Opportunity) which is overcoming the weaknesses and threats that exist by using the opportunity. One way that can be done is to make improvements in all fields and improvements in the system. With this, the owner can know how to survive in the intense competition and keep going in the situation of COVID-19 pandemic.

\section{Recommendations}

1) In connection to the feasibility study which has been done with various aspects, Kulo coffee shop mostly meets the criteria as a feasible business. However, as time goes by of course the changes will arise and encourage this business to be prepared. Thus, Kulo coffee shop Pemogan is expected to have more creative innovations, able to cooperate with other parties and governments to develop markets and marketing so that the business can survive in an increasingly strict competition. In the technical and technology aspects, what expected is mentoring and ongoing supervision so that the process and production results are following the standards owned by Kulo coffee shop.

2) Based on SWOT analysis, Kulo coffee shop Pemogan can now obtain the information regarding the position of their business. In addition to having strength as a business opportunity, this business has a weakness and threats that will adversely affect the business. Thus, Kulo coffee shop Pemogan is expected to face these weaknesses and threats by looking at the opportunities that exist through various strategies. The way that can be done is by improving the quality, offering innovative and creative products, and improving the system and service processes as well as easy transactions, especially in this COVID-19 pandemic that requires the owner to be more active.

\section{Conflict of interest statement}

The authors declared that they have no competing interests.

Statement of authorship

The authors have a responsibility for the conception and design of the study. The authors have approved the final article.

\section{Acknowledgments}

The authors would like to acknowledge the editor of IRJMIS for their support, valuable time, and advice in completing 


\section{References}

Barusman, A. R. P., \& Khunsu, K. (2013). Analisis Studi Kelayakan Pada Waralaba Excelso Di Bandar Lampung. Jurnal Manajemen Dan Bisnis, 4(1).

Cope, C. (1995). Creation of compression gastroenterostomy by means of the oral, percutaneous, or surgical introduction of magnets: feasibility study in swine. Journal of Vascular and Interventional Radiology, 6(4), 539545. https://doi.org/10.1016/S1051-0443(95)71131-9

Henderson, C. R., Manwell, J. F., \& McGowan, J. G. (2009). A wind/diesel hybrid system with desalination for Star Island, NH: feasibility study results. Desalination, 237(1-3), 318-329. https://doi.org/10.1016/j.desal.2005.07.054

Jani, M. R. (2018). Analisa Kelayakan Pengembangan Usaha Cafe Kawista Berdasarkan Aspek Pasar, Aspek Teknis Dan Aspek Finansial Di Kota Pekanbaru (Doctoral dissertation, Universitas Islam Negeri Sultan Syarif Kasim Riau).

Keizer, H. J., Karim, A. B. M. F., Njo, K. H., Tierie, A. H., Snow, G. B., Vermorken, J. B., \& Pinedo, H. M. (1984). Feasibility study on daily administration of cis-diamminedichloroplatinum (II) in combination with radiotherapy. Radiotherapy and Oncology, 1(3), 227-234. https://doi.org/10.1016/S0167-8140(84)80004-3

Khamaludin, K., Juhara, S., \& Sodikin, S. (2019). Studi Kelayakan Bisnis Bengkel Bubut Cipta Teknik Mandiri (Studi Kasus di Perumnas Tangerang Banten). Unistek, 6(1), 1-6.

Kogan, A. (1998). Direct solar thermal splitting of water and on-site separation of the products-II. Experimental feasibility study. International Journal of Hydrogen Energy, 23(2), 89-98. https://doi.org/10.1016/S03603199(97)00038-4

Kramers, J. D., \& Smith, C. B. (1983). A feasibility study of $\mathrm{U}-\mathrm{Pb}$ and $\mathrm{Pb}-\mathrm{Pb}$ dating of kimberlites using groundmass mineral fractions and whole-rock samples. Chemical Geology, 41, 23-38. https://doi.org/10.1016/S00092541(83)80003-5

Purnamasari, D., \& Hendrawan, B. (2013). Analisis Kelayakan Bisnis Usaha Roti Ceriwis sebagai Oleh-Oleh Khas Kota Batam. Jurnal Akuntansi, Ekonomi Dan Manajemen Bisnis| e-ISSN: 2548-9836, 1(1), 83-87.

Putra, R. T., \& Azis, E. (2018). Analisis Kelayakan Pembangunan Unit Bisnis Sangrai Kopi Pada Brewisely Coffeemate Ditinjau Dari Aspek Pasar, Aspek Teknis, Aspek Finansial. eProceedings of Management, 5(1).

Putri, N. A., Saidah, Z., Supyandi, D., \& Trimo, L. (2020). Analisis Kelayakan Bisnis Kedai Kopi (Studi Kasus Pada Agrowisata N8 Malabar, Pangalengan, Kabupaten Bandung). Journal of Food System \& Agribusiness, 3(2), 89100.

Rahayu, A. D. (2015). Analisis Kelayakan Usaha Gula Semut Anggota Koperasi Serba Usaha (KSU) Jatirogo.

Rangkuti, F. (1998). Analisis SWOT teknik membedah kasus bisnis. Gramedia Pustaka Utama.

Romdhon, M. M., Andani, A., \& Ayu, A. M. (2018). Sensitivitas Kelayakan Finansial Pengolahan Kopi Bubuk. Jurnal AGRISEP Kajian Masalah Sosial Ekonomi Pertanian dan Agribisnis, 17(1), 31-38.

Roth, R. A., \& Aretz, H. T. (1991). Transurethral ultrasound-guided laser-induced prostatectomy (TULIP procedure): a canine prostate feasibility study. The Journal of urology, 146(4), 1128-1135. https://doi.org/10.1016/S00225347(17)38024-2

Sugiyono, A. (1997). Mamberamo Related Information on the WEB.

Unno, N., Suzuki, M., Yamamoto, N., Inuzuka, K., Sagara, D., Nishiyama, M., ... \& Konno, H. (2008). Indocyanine green fluorescence angiography for intraoperative assessment of blood flow: a feasibility study. European Journal of Vascular and Endovascular Surgery, 35(2), 205-207. https://doi.org/10.1016/j.ejvs.2007.09.001

Winantara, I. M. Y., Bakar, A. B. U., \& Puspitaningsih, R. (2014). Analisis Kelayakan Usaha Kopi Luwak Di Bali. Reka Integra, 2(3).

Wulandari, P. T. (2012). Analisis kelayakan finansial pengembangan usaha kecil menengah (UKM) nata de coco di Sumedang, Jawa Barat. Asian Journal of Innovation and Entrepreneurship, 1(02), 113-120.

Sudiartini, N. W. A., Astari, A. A. E., Kardini, N. L., \& Dhani, Y. R. (2020). The feasibility study of coffee house business opportunity in COVID-19 pandemic: a case study at kulo coffee shop pemogan. International Research Journal of Management, IT and Social Sciences, 7(5), 38-45. https://doi.org/10.21744/irjmis.v7n5.966 